EESTI NSV TEADUSTE AKADEEMIA TOIMETISED, 25. KOIDE KEEMIA * GEOLOOGIA. 1976, Nr. 3

ИЗВЕСТИЯ АКАДЕМИИ НАУК ЭСТОНСКОН ССР. ТОМ 25 ХИМИЯ * ГЕОЛОГИЯ. 1976, № 3

Э. КАЛА

удК $551.733 .3(474.4)$

\title{
ВЕРХНЕСИЛУРИЙСКИЕ ОТЛОЖЕНИЯ НА МАТЕРИКОВОЙ ЧАСТИ ЭСТОНИИ
}

\section{E. KALA. MANDRI-EESTI ULEMSILURI SETTED}

E. KALA, UPPER SILURIAN DEPOSITS IN THE CONTINENTAL PART OF ESTONIA

До 70-х годов единственным известным районом распространения верхнесилурийских отложений в Эстонии был о. Сааремаа (Кальо, ред., 1970). Вопрос о том, сохранились ли эти отложения от последней длительной денудации где-нибудь еще на территории республики, долгое время оставался открытым. Проведенная в 1969-1971 гг. под руководством автора государственная среднемасштабная геологическая съемка Западной Эстонии (включая о. Сааремаа) дала на этот вопрос положительный ответ (рисунок). Верхнесилурийские отложения вскрыты на материке (скв. 502, Варбла), в 10 км северо-западнее пос. Тыстамаа, в интервале $19,0-49,8$ м. а также на островах Кихну (скв. 526) и Рухну (скв. 500) в интервалах $85,8-108,3$ и $147,3-177,0$ м соответственно.

В разрезе скв. Варбла эти отложения представлены слабоглинистыми тонко- и микрокристаллическими доломитами светло-серого цвета, на фоне которого в верхней части выделяются фиолетово-красные пятна. В нижней части (примерно 15 м) эти доломиты содержат маломощные прослойки с пластовыми строматолитами $(36,9-37,0 ; 38,2 ; 41,1-42,3$; $47,6 ; 50,8-51,1 м)$, мелкими известковыми оолитами $(33,9-34,7 ; 40,8-$ 41,$1 ; 43,4-43,7$ м) и редкими онколитами $(34,0-34,8 ; 43,0-43,4 ; 43,7$ м). На основе литологического сходства разреза скв. Варбла с разрезами о. Сааремаа, где установлены те же прослойки, оказалось возможным выделить здесь в интервале $33,4-49,8$ м роотсикюлаский горизонт со всеми его подразделениями. При геологической съемке вышезалегающие слои были отнесены сначала к паадласкому горизонту, однако впоследствии расчленение было уточнено по палеонтологическим данным (Эйнасто и др., в печати).

Роотсикюлаский горизонт, как известно, подразделяется (снизу вверх) на вийтаские, куусныммеские, везикуские и соэгининаские слои (Кальо, ред., 1970).

На основе макролитологического сходства разрезов скв. Варбла и о. Сааремаа удалось уточнить положение везикуских слоев (интервал $43,7-41,1$ м), ограниченных сверху и снизу поверхностями размыва и имеющих цикличное строение. Они представлены доломитами, содержащими внизу много зернистого материала (мелких обломков доломита, известковых оолитов и онколитов) и переходящими вверх в илистые микрослойчатые тонко- и микрокристаллические доломиты (см. рис. 1 Эйнасто и др., в печати). Верхняя часть везикуских слоев сложена мас- 


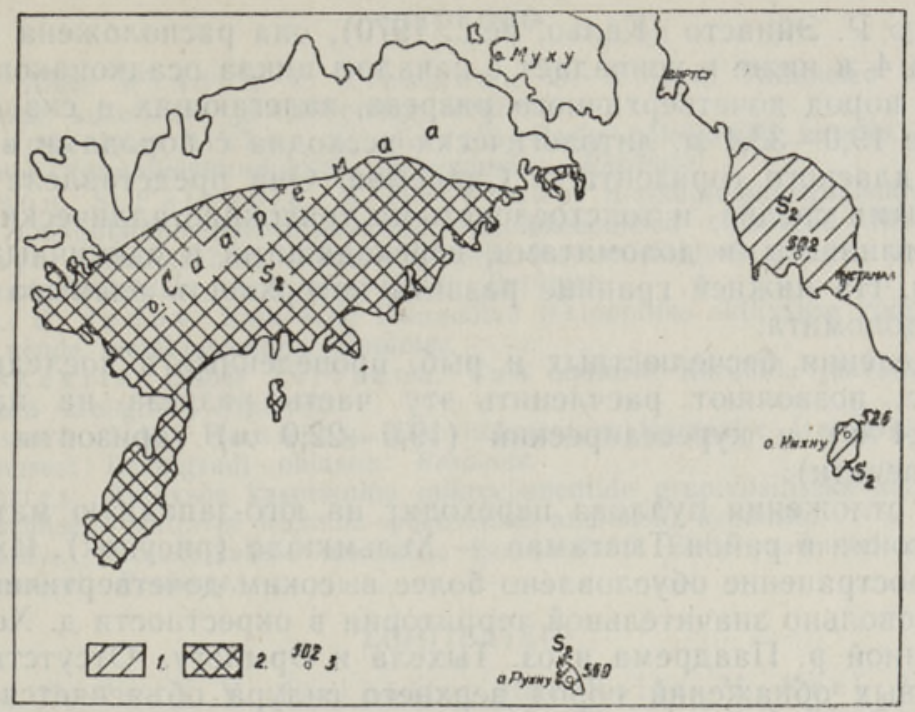

Обзорная карта распространения верхнесилурийских отложений: 1 - новые районы, 2 - ранее известный район, 3 - новые буровые скважины (500 - скв. Рухну, $502-$ скв. Варбла, 526 - скв. Кихну).

сивными биоконструктивными доломитами (пластовым строматолитом) мощностью 1,2 м, которые, по мнению Р. Эйнасто, имеют непрерывное площадное распространение на всей территории о. Сааремаа.

Выше, в интервале $33,4-41,1$ м, несколько условно выделены соэгининаские слои, представленные светло-серыми толстослоистыми тонкокристаллическими доломитами, кавернозными в верхней части и содержащими прослойки микрокристаллического доломита в нижней. В кавернозной части прослеживаются выщелоченные оолиты, строматолиты, онколиты, трудно определимые тонкостенные раковины и табуляты. На обеих границах развиты поверхности размыва (см. рис. 1 Эйнасто и др., в печати).

В данном разрезе не удалось достаточно хорошо выделить куусныммеские (интервал 46,2-43,7 м) и вийтаские (интервал 46,2-49,8 м) слои (см. рис. 1 Эйнасто и др., в печати). Первые представлены неравномерно узорчатыми микро- и тонкокристаллическими доломитами от желтовато-серых до темно-серых тонов, а вторые - микрокристаллическими доломитами серого цвета, переходящими вниз в доломитовые домериты с характерным темно-серым узором пиритизации и слабой микрослойчатостью.

Нижняя граница роотсикюлаского горизонта, а соответственно, и вийтаских слоев определялась исследователями в разное время по-разному (Аалоэ, 1960; Einasto, 1961; Аалоэ, Кальо, 1962; Эйнасто, 1962; Кальо, ред., 1970). Нами она устанавливается по поверхности размыва на контакте узорчатых микрослойчатых доломитов и домеритов (вийтаские слои) с нижележащими толстослонстыми светлыми доломитами (яагарахуский горизонт), содержащими выщелоченные известковые оолиты, детрит и кораллы. Эта нижняя граница по отдельным скважинам была установлена ранее (Эйнасто, 1962; Аалоэ, Кальо, 1962). Нами она довольно отчетливо фиксируется по следующим буровым скважинам: Рухну на глубине 275,5 м; Кихну - 108,3 ; ; Тыстамаа - 53,7 ; Саaре - 18,7 м; Лаймъяла - 16,3 м; Кингисепп - 72,2 м и т. д. Однако 
по мнению Р. Эйнасто (Кальо, ред., 1970), она расположена приблизительно на $4 м$ ниже и совпадает с началом цикла осадконакопления.

Часть пород дочетвертичного разреза, залегающих в скв. Варбла в интервале $19,0-33,4$ м литологически несходна с породами вышележащего паадлаского горизонта о. Сааремаа. Она представлена довольно однородными средне- и толстослоистыми тонкокристаллическими неравномерно глинистыми доломитами, переходящими в единичных слоях в домериты. На нижней границе развита поверхность размыва с мелкой галькой доломита.

Определения бесчелюстных и рыб, проведенные в последнее время Т. Мярсс, позволяют расчленить эту часть разреза на паадлаский $(22,0-33,4$ м) и курессаареский $(19,0-22,0$ м) горизонты (Эйнасто и др., в печати).

Итак, отложения лудлова переходят на юго-западную материковую часть Эстонии в район Тыстамаа - Хельмкюла (рисунок). Их площадное распространение обусловлено более высоким дочетвертичным рельефом на довольно значительной территории в окрестности д. Хельмкюла, ограниченной р. Паадрема и оз. Тыхела и Эрмисту. Отсутствие здесь естественных обнажений пород верхнего силура объясняется, с одной стороны, большой мощностью покрывающих их четвертичных отложений, а с другой - погружением дочетвертичного рельефа на юг, в сторону моря. В приустьевой части р. Паадрема обнажаются только однородные доломиты нижележащего яагарахуского горизонта.

Как известно, верхнесилурийские доломиты о. Сааремаа представляют собой ценный строительный материал, который успешно используется для декоративных отделочных работ. Поэтому поиски таких же строительных материалов целесообразно начать и на материковой части распространения верхнего силура.

Автор искренне благодарен сотрудникам Института геологии АН ЭССР Р. Эйнасто, Т. Мярсс и Э. Марк-Курик за оказанную многостороннюю помощь при изучении этого разреза.

\section{ЛИТЕРА Т У Р А}

А а л о э А. О. 1960. Новое в стратиграфии силура Эстонии. Тр. Ин-та геол. АН ЭССР, V. А ал оэ А. О., К альо Д. Л. 1962. Краткий обзор разреза силурнйских отложений в скв. Охесааре (о. Сааремаа). Тр. Ин-та геол. АН ЭССР, Х.

К альо Д. Л. (ред.) 1970. Силур Эстонни. Таллин.

Эй н а сто Р. Э. 1962 . Сопоставление основных разрезов каармаского горизонта. Тр. Ин-та геол. АН ЭССР, $\mathbf{X}$.

Э й н а с т о Р., М я р с с Т., К ала Э. Стратиграфическое расчленение верхневенлокскодаунтонской доломитовой толщи в разрезах Сакла, Варбла и Кихну. Изв. АН ЭССР, Хим. Геол., (в печати).

E in a s to R. 1961. Kaarma lademe piiridest ja paksusest uute puuraukude alusel. Geoloogilisi märkmeid II. Loodusuurijate Selts. Tartu.

Управление геологии

Совета Министров Эстонской ССР

Поступила в редакцию $22 / \mathrm{IX} 1975$ 